Vol. 18, $n^{\circ} 1$ | 2014

Varia

\title{
Youth, Literacy and Social Emancipation in Third Republic France : The 'Crime de Jully'
}

\section{Briony Neilson}

\section{(2) OpenEdition \\ 1 Journals}

\section{Electronic version}

URL: http://journals.openedition.org/chs/1468

DOI: 10.4000/chs.1468

ISSN: 1663-4837

\section{Publisher}

Librairie Droz

\section{Printed version}

Date of publication: 1 July 2014

Number of pages: $81-100$

ISBN: 978-2-600-01935-4

ISSN: 1422-0857

\section{Electronic reference}

Briony Neilson, «Youth, Literacy and Social Emancipation in Third Republic France: The 'Crime de Jully' », Crime, Histoire \& Sociétés / Crime, History \& Societies [Online], Vol. 18, n 1 | 2014, Online since 01 July 2017, connection on 17 March 2020. URL : http://journals.openedition.org/chs/1468 ; DOI https://doi.org/10.4000/chs.1468 


\title{
Youth, Literacy and Social Emancipation in Third Republic France: The 'Crime de Jully'
}

\author{
Briony Neilson'
}

Cet article analyse la réaction sociale au "Crime de Jully", une affaire d'assassinats multiples commis dans la France rurale en 1909-1910 par deux vachers adolescents d'origine suisse. Alphabétisés et ambitieux, ces garçons prétendirent avoir été conduits au meurtre par leurs lectures. Pour la société française de leur époque, Richard Joseph Jacquiard et Joseph Vienny représentaient des personnalités marginales et dangereuses, en tant que criminels, adolescents (ni enfants, ni adultes), et travailleurs éduqués. Bien qu'ils n'eussent pas été élevés ou éduqués en France, la réaction s'inscrivit dans le cadre d'un débat national concernant les effets de l'instruction lä̈que et obligatoire qui avait débuté plusieurs décennies auparavant. Comme le montre cet article, en exigeant que tous les enfants allassent à l'école primaire, les autorités républicaines affrontaient un dilemme fondamental: comment éduquer la jeunesse sans déstabiliser l'ordre social.

This article analyses the social response to the 'Crime de Jully,' a multiple murder case committed in rural France in 1909-1910 by two Swiss adolescent cowherds. Literate and ambitious, the boys claimed that they had been driven to murder because of their reading habits. Richard Joseph Jacquiard and Joseph Vienny represented dangerous liminal figures for contemporary French society: as criminals, adolescents (neither children nor adults), and as educated workers. Although the boys had not been educated or raised in France, the response was framed within a decades-long national debate over the effects of compulsory, secular education. As this article explores, in requiring all children to attend primary school republican authorities faced a fundamental dilemma: how to educate young people while not destabilizing the existing social order.

Tn early June 1910, an eager audience packed into the Auxerre assizes court to witness the sensational trial of seventeen-year-old Richard Joseph Jacquiard

Briony Neilson received her PhD in History from the University of Sydney in 2012. Her thesis, entitled The Age of Morality: Youth, Criminal Responsibility and Juvenile Justice Reform in Third Republic France, 1877-1912, explored ideas about age, regeneration, and criminality in Third Republic France, especially in relation to judicial practice and emerging ideas about childhood and adolescence as distinct stages of moral development. Her current research examines social responses to popular literacy in France in the nineteenth century, particularly in the context of a widening of the political franchise. 
and fifteen-year-old Joseph Vienny, two Swiss cowherds charged with five counts of murder. It was a violent case. Late one afternoon the previous December, in the small Burgundian hamlet of Jully, the boys had carried out a series of cold-blooded attacks, brutally slaughtering their employer Auguste Verrières and his wife, along with the couple's domestic servant and two of their fellow farmhands. The boys' immediate motive had been money: they intended to steal from the Verrières in order to fund their passage from Marseilles to Africa where they would become hunters, make their fortune and publish stories of their adventures. As the elder of the pair, Jacquiard was generally considered the mastermind behind the plot and it was he who attracted the greatest attention from the press and prosecutors. Although theft was the boys' immediate motive, it transpired that it had not been pure avarice, but rather reading which had originally drawn them to commit their crime-the seed of ambition for lives of adventure and fame in Africa had been sown by the various books and magazines that they avidly read and collected. A significant aspect of the "crime de Jully", as it was known, was the fact that as well as being consumers of culture, the boys (especially Jacquiard) also harboured ambitions of shaping culture by becoming writers. This collision of cultural ambition, social aspiration and criminal deviance was read at the time as clear evidence of the dangers of democracy and universal education. Indeed what the case seemed to suggest was that, rather than insuring against deviance, as was the customary contention of republicans, education had actually provided the vehicle for it.

While the "crime de Jully" has not been entirely forgotten (at least, not by French-speaking scholars), the amount of scholarly attention dedicated to it has been small. The extant analysis has merely scratched the surface of the case for what it reveals about attitudes to youth, education and social emancipation-the main themes of this article. ${ }^{2}$ In some respects the "crime de Jully" anticipated the 1924 "Leopold and Loeb" case in Chicago, with its central characters of educated and morally dissolute youths. ${ }^{3}$ But whereas in the Chicago example the violence and perversity of the young murderers were seen to make them aberrant examples of their class - middle-class boys gone bad - in the earlier French case, by contrast, it was the boys' unfitting cultural ambitions that made them especially transgressive. Contemporary observers entertained various explanations for the boys' delusions: from their family backgrounds to their mental health, from parental neglect to institutional mistreatment, from itinerant labour to unedifying literature, from inappropriate education to psychological theories about the inherent instability of adolescence as a life stage. Beneath all of these explanations lay an anxiety about the marriage of culture and criminality.

Historians have long identified the link between criminality and social transgression, however their analyses have concentrated principally on its manifestation in terms of categories of class and gender, leaving age largely underscrutinized. ${ }^{4}$ While hardly an unfurrowed field, scholars (especially sociologists and historians) have principally explored the question of childhood in terms of

Camus, Diey (2009); Kalifa (1995, p. 228); Fontaine (2005, pp. 87-92); Ambroise-Rendu (2004).

Fass (1993).

4 Chevalier (1958); Berenson (1993). For background into the study of transgression and deviance, see the pioneering work by Becker (1973). 
State intervention in family life. ${ }^{5}$ It might be argued that the reasons for historians' comparative neglect of the relationship between age, citizenship and deviance are self-evident : the concept of the child, acting as a point of reference against which the notion of adulthood is defined, is considered more stable and less contentious than other central categories of race, class and gender. Moreover young people experience only a temporary period of subjection on account of their age. Being in a period of growth, the young are only denied their full rights of citizenship until they attain maturity. While as a component of identity it may to a great extent be secondary to others, age can nonetheless be informative. Indeed, as this article attempts to demonstrate, in France at the start of the twentieth century, ideas about youth and criminality were tied up with concerns about democracy, education (especially literacy) and social stability.

The analyses of the relationship between the dangerous effects of mass literacy and democratic values offered by historians such as Ann-Louise Shapiro and Robert A. Nye, while illuminating, have been similarly uninformative about age as a crucial category. ${ }^{6}$ When historians have turned their attentions specifically to the connection between youth criminality and popular culture at the end of the long nineteenth century, their focus has tended to fall primarily on the most visible and terrifying youth type in French culture at the time: the apache. The French equivalent of the British hooligan, the apache was held up as evidence of the social and moral degeneration of contemporary youth in the decades before the First World War. ${ }^{7}$ In France, as in Britain, the moral panic about precociously violent youths was part of a broader preoccupation with the increasing independence of the working class. ${ }^{8}$ Such concerns were hardly new. For instance, when observers in early nineteenth-century Britain addressed the juvenile crime problem their interest went beyond simply a concern about young people breaking the law. Indeed, as one scholar has put it: "“crime' was becoming a vehicle for articulating mounting anxieties about issues which really had nothing to do with crime at all: social change and the stability of social hierarchy." 9

Given its omnipresence, it was inevitable that the apache would provide a key point of reference for journalists' representations of Jacquiard and Vienny. In one report, the Petit Parisien newspaper labelled them "The Swiss "Mohicans"'-a variation of the apaches tag. ${ }^{10}$ But at the same time, the boys' departure from the apache mould also gave journalists further criteria by which to emphasize their exceptionality, making them at once more monstrous on an individual level and more reassuring on a general one, as Anne-Claude Ambroise-Rendu has astutely argued. ${ }^{11}$ Certainly, there were many facets of the Jully case that set it apart from the ordinary run-of-the-mill: the scale of the boys' violence and the bucolic setting of the

5 See, for instance, Donzelot (1977); Meyer (1977); Schnapper (1980); Schafer (1997); Faron (2001); Toth (2010). While Norris (2000) explores ideas about childhood and modernity in her doctoral dissertation, her emphasis is on psychology and education rather than more broadly on politics.

6 Shapiro (1996, p. 47); Nye (1975, especially chapters 4, 5 and 7).

7 On the apaches, see Kalifa (1995, pp. 152-161); Nye (1984, pp. 196-223); Perrot (2001).

8 For the English context, see Pearson (1983, pp. 167 \& 74-75); Hendrick (1990, p. 5).

9 Hendrick (2006, p. 5).

10 Petit Parisien, 14 December 1909.

11 Ambroise-Rendu (2004, p. 223). 
crime. However, it is important to resist concentrating simply on its exceptionality as this clouds our view of the ways in which it tapped into profound, existing anxieties concerning young people, education and the building of democracy.

The primary objective of this article is not to account for all the interwoven - and often opposing - narrative strands of this sensationalist crime and trial. Instead, the aim (in addition to restoring the case to the prominent position it once enjoyed) is to use the case as a launching pad to unpack the underlying concerns that it aroused, concentrating particularly on the tensions between age, education, and democracy. ${ }^{12}$ Responses to the actions of Jacquiard and Vienny demonstrate the considerable prominence of matters concerning age and responsibility in French society in the years before the First World War. Drawing on the judicial file held at the Archives départementales de l'Yonne (which, as we shall see, contains remarkable samples of the boys' writings), newspaper accounts, journal articles (both specialized and general), criminal justice monographs and reform society proceedings, this study ultimately aims to explore the connections drawn in the early twentieth century between crime and culture, and, on a more general level, to demonstrate the utility of considering representations of criminality and social transgression through the lens of age. This focus complements the existing strong body of research on citizenship in the Third Republic and its links to social control and the curtailing of "deviant" behaviours. ${ }^{13}$ Following a discussion of newspapers' representation of the case, the analysis addresses the debate over the role played by literacy and compulsory primary education in fostering social cohesion. This article offers a contextual analysis of the case, revealing how contemporary observers' discussions on the adolescent cowherds' criminal acts, cultural tastes, and social ambitions acted as a proxy for debating broader questions concerning France's transition to a liberal democracy.

\section{SENSATIONALISM: THE ‘CRIME DE JULLY’ AS FAIT DIVERS}

Right from the start, the crime, shocking in its brutality and unusual in its isolated, rural setting, attracted scores of curious onlookers and swarms of newspaper journalists, keen to dissect and communicate even the smallest details to their readers. It was a classic sensationalist case, its atypicality explained its hold on the public imagination, and the press played a pivotal part in forming and feeding the fascination. The incongruousness of the perpetrators as criminals provided journalists with a hook on which they could secure the public's ongoing attention. From a historical point of view, too, the interest lies in its various levels of transgression. Jacquiard and Vienny defied expectations of appropriate young behaviour and were regarded as monsters - a common label applied to criminals - not just on account of the brutality of their crime but because of the degree of unsettling precocity and premeditative planning it revealed. ${ }^{14}$ The scale of the carnage, the youth of the culprits and their apparent moral impassiveness - manifesting during the trial a reticence and lack of

For more on these themes, see Neilson (2012).

13 See Elwitt (1975); Stone (1985); Surkis $(2001,2006)$. For a more general analysis of the intimate and insidious connections between democracy, liberalism and social control, see Rose (1997).

14 On the representation of criminals as monsters, see Chauvaud (1991). For more on medical theories of criminality in this period, see Nye (1984); Harris (1989). 
emotions - suggested nothing short of a collapse of the moral order. Spectators at the trial and readers of newspapers were encouraged to compare and contrast the behaviour of Jacquiard and Vienny with one of their victims, Louis Imbert, who had survived the attack and had been the first to raise the alarm. His efforts awarded with a medal for bravery, Imbert was described by the Figaro as "a brave little child, with a sound and clear conscience." 15

During the investigation and the trial, journalists picked over every aspect of Jacquiard and Vienny's behaviour and physical appearance. The simple fact of the boys' diminutive physical stature made the audacity of their crime all the more shocking. ${ }^{16}$ The clash between their physical immaturity and the atrocity of the crime became a common feature of journalists' descriptions. Swiss newspaper the Gazette de Lausanne was among those that emphasized the boys' appearance, and asked how such youths could commit such a dreadful crime. ${ }^{17}$ Jacquiard's appearance, in particular, attracted substantial comment. Journalists described his sallow complexion, his small, hooded, and blinking eyes, and his thin lips, which, they remarked with distaste, seemed to curl into a vague smile. ${ }^{18}$ They commented on both boys' lack of emotional response, their detachment and apparent cynicism - all seen to signify an absence of moral conscience and an unambiguous lack of remorse. One journalist remarked that witnessing the defendants' impassive responses was like watching an exhibition of monsters. ${ }^{19}$ Even immediately after their arrest the boys' lack of emotion was remarked on; Jacquiard was described as speaking with "a muffled voice, without apparent emotion, as if he were recounting events he had seen as a simple witness." 20

Deep-rooted assumptions about children's innate goodness made the very appearance of young people in court disconcerting. ${ }^{21}$ The fact that Jacquiard and Vienny appeared before the assizes court - which only heard the most serious crimes that carried the harshest penalties - further emphasized both the case's gravity and their own exceptionality. In an article published in 1913, jurist Henri Robert touched on the implicit contradiction of the young criminal, exclaiming: "Crime and youth! These are two words which clash and shriek to find themselves coupled together!"22 In a subsequent lecture Robert reiterated these views, declaring that "children should not cause us any trouble ... even of the lightest kind." 23 On the eve of the trial Georges Claretie, journalist for the conservative Figaro newspaper, emphasized the uniqueness of the circumstances of the crime - a standard tecnique in the construction

15 Le Figaro (4 June 1910). The youthful rescuer was a common archetype in Third Republic culture, used as an antidote to the proliferating example of the juvenile delinquent. Olivier (2009).

16 At the time of their arrest, Jacquiard measured just 1 metre $60 \mathrm{~cm}$, and Vienny 1 metre $49 \mathrm{~cm}$. Archives départementales de l'Yonne, 2Y 38 (17 March 1892, 21 July 1924, 'detainees', 369 \& 370).

17 Gazette de Lausanne (14 December 1909).

18 Le Figaro (4 June 1910).

19 Le Figaro (4 June 1910).

20 Le Petit journal (15 December 1909).

${ }^{21}$ Nilan (1992, p. 45). See also Nilan (1997) and, for comparison with the British context, Jackson (2000).

22 Robert (1913, p. 100). Robert Nye has labelled Henri Robert "the greatest criminal lawyer - and manipulator of juries - of his generation." Nye (1984, p. 214).

23 Robert (1913, p. 382). 
of a sensationalist narrative. The case was "unique in the annals of crime". ${ }^{24}$ Claretie also emphasized the boys' (especially Jacquiard's) exceptionality. Jacquiard was "a being such as had never been seen before in any society or at any time." 25

Militant Catholic newspapers, such as the Courrier de la Montagne (from the Franche-Comté region in eastern France) and the Lille-based Croix du Nord, depicted Jacquiard and Vienny as agents of the devil, the inevitable product of immoral (that is, secular) modern society. One report, published several months after the trial took place in 1910, proclaimed that "the current generation bears on its forehead the sign of the beast described in the apocalypse." The reason for this stamp by the devil, was secular primary schooling: "the School of God and its sublime hopes have been closed to young men, the School without God has been created and the State has applied itself to educating non-believing generations ignorant of their eternal destinies." ${ }^{26}$ In the vehement battle between Church and State, which reached a particular crescendo in the decades before the First World War, Jacquiard and Vienny became poster-boys for an attack led by Catholic conservatives against the alleged social and material progress of modern times. As we shall see, notwithstanding the fact that they had been educated in Switzerland and not France, the two boys were seen as emblems of a growing proportion of morally degenerate youths.

In contrast to the Catholic press' allegations that youth criminality was the product of secular State education, the left-wing Toulouse daily La Dépêche painted a different portrait, looking to contemporary theories of psychology for insights into the causes of the boys' actions, and privileging science over religion. ${ }^{27}$ Rather than portraying Jacquiard as an incurable degenerate, the Dépêche painted the boy as a victim, let down by society because he had not been given appropriate treatment after committing a minor offence several years earlier. ${ }^{28}$ To allegations made in "reactionary newspapers" that atheism lay behind their dreadful deeds, the Dépêche reminded readers that the boys were, in fact, "two young members of the flock of the Christian school," and raised in the "very Catholic canton of Fribourg." ${ }^{29}$ Crime, in short, could not be seen as the immediate outcome of a universal, secularized system of education.

\section{LITERACY AS MORAL POISON}

The alleged link between reading and crime tapped into an ongoing public debate about the relationship between compulsory education and social instability, the most extreme manifestation of which was criminality. Concern in France at this time about the effects of literacy on popular morality and social structures was at a particular height and was directed primarily at women, workers and young people. Our own society's concern about falling rates of reading, as Martyn Lyons has observed, is a precise inversion of the nineteenth-century anxiety over the ever expanding

\footnotetext{
$24 \quad$ Le Figaro (3 June 1910).

25 Le Figaro (5 June 1910).

26 Le Courrier de la Montagne (25 September 1910).

27 Boncour, quoted in Dépêche (de Toulouse) (5 June 1910).

28 La Dépêche (de Toulouse) (5 June 1910).

29 La Dépêche (de Toulouse) (21 December 1909).
} 
and voracious readership of books and newspapers. ${ }^{30}$ Greater literacy was seen to have an effect on labourers' ability to knuckle down at work. ${ }^{31}$ For criminal justice reformers, the "crime de Jully" provided an anchor for their discussions on the role of literature in inciting violence, and a salutary lesson in the problems of an overly liberal attitude to publishing. Evidence already existed indicating the predilection of young readers, among them detainees in Petite Roquette prison, for tales of adventure and exploration, including the stories of Jules Verne. ${ }^{32}$ A journalist for the Dépêche newspaper remarked that Jacquiard and Vienny's reading habits were no different from those of hundreds of thousands of other children who did not commit criminal acts. ${ }^{33}$

The reading habits of Jacquiard and Vienny were raked over during their trial. According to his half-sister, it was books that had ruined Jacquiard, and his passion for the written word was apparently shared by other members of his family. ${ }^{34}$ One local French newspaper reported that two of Jacquiard's aunts had also been insatiable readers and their literacy had produced equally disastrous consequences: one had been institutionalized, the other had killed herself. ${ }^{35}$ Jacquiard's collection of books was evidently central to his identity and his most prized possessions. Although it was not standard practice for itinerant workers to take reading materials with them on their travels, ${ }^{36}$ when he had moved from Switzerland to France Jacquiard had brought his treasured collection with him, the titles and issue numbers itemized in one of his personal notebooks. ${ }^{37}$ So central was his mobile personal library to his general well-being that while incarcerated and awaiting the appeal to his conviction, Jacquiard issued an official request to authorities to be reinstated with his "library" of more than three hundred volumes, along with a request for a photograph of his late mother, because, he declared, they would "allow me to entertain myself during my detention and I will be better able to await death - if I am to be executed." 38

Educated at the same primary school at Orsonnens, a small village south-west of Fribourg, both Jacquiard and Vienny had acquired basic literacy and numeracy. Their teacher, Henri Grivel, later told investigators that although Jacquiard had lacked motivation to complete tasks, he was rather talented and had a superior memory. ${ }^{39}$ The boys' reading habits provided a point of fascination. But even more than their reading, it was their writing - Jacquiard's especially - that attracted particular attention from journalists and other commentators. For not only was Jacquiard a consumer of culture, his jottings revealed a strong aspiration to contribute to it. Hot on the trail of the escaped killers, locals had stumbled upon suitcases jettisoned by

\footnotetext{
$\overline{30}$ Lyons (2008, p. 5).

31 When "penny dreadfuls" became common in Britain employers regularly complained that it was almost impossible to get office boys and errand runners to work. Altick (1957, p. 251).

32 Joly (1888, p. 310). Guillot (1893, p. 462). Guy Tomel and Henri Rollet similarly noted the predilection of young readers for the stories of Jules Verne. Tomel, Rollet (1891, p. 8).

33 La Dépêche (de Toulouse) (21 December 1909).

34 Le Figaro (5 June 1910).

35 L'Écho du Tonnerrois (23 December 1909).

36 Altick (1957, p. 95).

37 Archives départementales de l'Yonne, 2U 260, notebook belonging to Richard Joseph Jacquiard.

38 Reported in both La Gazette de Lausanne and Le Temps (14 July 1910).

39 Archives départementales de l'Yonne, 2U 260, Statement of Henri Grivel.
} 
Jacquiard and Vienny in a forest not far from the Jully farm. Among the clothes and other possessions the boys had abandoned to speed up their flight, their pursuers discovered a collection of personal documents, including letters, account books, and general notebooks.

Swiss newspaper Liberté managed to get access to one of these notebooks belonging to Jacquiard, ostensibly with the aim of locating a rational motive for the boys' savage crime. On the cover of the forty-page school exercise book was written "Joseph Jacquiard" and the date, "5 December 1908" - just over a year before the fateful day of the crime. One-third of the notebook was filled with schoolwork, the bulk of it quite clearly transcribed from textbooks, and featuring descriptions of wild animals and exotic lands. Beneath the final lesson, dated "17 March 1909," Jacquiard had signed his name and written his date of birth, the dates of the first and last day of schooling, the names of his godparents, and those of his mother and his father.

There was nothing particularly gripping in the contents of these jottings. However, on the next page of the notebook, the focus and register of the writing changed. Jacquiard had written what amounted to the rough beginnings of a personal memoir. He listed the names, birth dates and other details about his parents, siblings, half-siblings, and ancestors, and recorded the main events of his family members' lives. The Liberté journalist remarked that "the young genealogist established this nomenclature with a surprising clarity and precision," and baulked at the fact that "this work of meticulous biography was the work of a child of fifteen." Jacquiard's family portrait included a glowing tribute to his beloved late mother, which was described as having been written in "a tone of tender admiration, poetic, and a little novelistic." Having paid homage to his mother, Jacquiard then outlined the life of his father and other members of his family before turning to his own life. In effect, he composed a sort of crude autobiography, more a basic chronicle for posterity than a sensitive attempt at self-reflection. "The autobiography," observed the Swiss journalist "is written in a simple and correct style, in a narrative tone free from personal display - despite the fact that the author is speaking of himself." ${ }^{40}$ Much of the detail in Jacquiard's descriptions was remarkably compressed. His account of his years of schooling, for instance, amounted to just a single statement and referred only to the weather conditions of his first and last days of attendance: "I began school on 2 March 1900 at Orsonnens in magnificent weather and I finished on 18 March 1909 in fine and sunny weather." ${ }^{41}$

While limited in its imaginative scope and frames of reference, and often superfluous in its detail - for instance, Jacquiard included the date he was vaccinated the boy's writing nonetheless displayed a familiarity with some essential conventions of composition and description, which suggested some literary potential. Jacquiard, the Liberté reporter wrote, clearly had a certain type of precocious intelligence since "fifteen-year-old genealogists are rather rare!" As was typical of newspapers' representation of the case, the Swiss journalist underlined the disjuncture of elements, contrasting Jacquiard's tender description of his mother with his brutal crime: "reading this notebook, we are so far from the Jully crime that, so astounding is the contrast, it would need a tremendous effort to say: the adolescent who wrote

40 La Liberté [de Fribourg] (15 December 1909).

${ }^{41}$ Archives départementales de l'Yonne, 2U 260, notebook of Richard Joseph Jacquiard, dated 5 December 1908. 
these pages and who speaks so piously of his mother killed five people with an axe, a revolver, and a dagger !" 42 But in addition to asserting the contrast between the tone of Jacquiard's writing and the violence of his criminal actions, the social response to these two young criminals was refracted through a perceived cultural tension concerning political emancipation and crime.

\section{EDUCATION, CLASS AND THE PARADOX OF REPUBLICAN IDEOLOGY}

Although Jacquiard and Vienny were born, raised, and educated in Frenchspeaking Switzerland, their criminal actions were framed within a French debate on domestic issues. In particular, the case provoked discussion on the merits of compulsory, secular education which produced over-educated, under-disciplined working-class youths. Such young French people were considered at chronic risk of developing into a population of déclassés and déracinés - an idea particularly associated with the work of Maurice Barrès, who warned of the negative effects that exposure to Enlightenment philosophy had on young readers. The consequences of unhealthy reading, powerfully demonstrated by Jacquiard and Vienny, were serious : they detached young people from their surroundings and led to dislocation and social breakdown. Barrès held republican education accountable for tearing the French nation apart by destroying traditional family and social structures and for producing a population of well-educated, ambitious young people who, indoctrinated in their freedoms and rights, were unwilling to submit to authority or respect existing social (including generational) hierarchies. ${ }^{43}$

There was some comfort to be drawn from the fact that Jacquiard and Vienny were not of French nationality. ${ }^{44}$ Some French newspapers highlighted Jacquiard and Vienny's origins more than others. The French weekly Le Courrier de la Montagne was a case in point, its greater emphasis on the boys' non-French origins explained by its proximity to the Swiss border. Swiss migrants were regularly painted as posing a threat to employment, while Italian migrants were characterized as violent. Mountain dwellers of the Doubs described the presence of large numbers of Swiss in the town of Pontarlier to the south as "Helvetic colonization". ${ }^{45}$ On the whole, however, the French press did not dwell much on the boys' national origins - a sign perhaps that concerns about youth criminality trumped those of Swiss invasion.

Even if they resided in the countryside, rather than the "dangerous city", ${ }^{46}$ and had been educated in Switzerland, not France, Jacquiard and Vienny were nonetheless seen by much of the French press to embody a certain identifiable type of disaffected

$\overline{42} \quad$ La Liberté [de Fribourg], 15 December 1909.

43 Barrès (1897).

44 The Parisian newspaper Le Matin noted that even though it was a relief to the national conscience that the two boys were not French, the case nevertheless offered the opportunity to "confront the problem of the criminality of children, and to study it, not just as a polemical argument, but as a laboratory experiment of interest to all humanity." Le Matin, 19 December 1909.

45 Ambroise-Rendu (2004, pp. 269-270).

46 Statistics seemed to prove that cities were particularly menaced by criminal activity, with crime rates per capita especially high in urban centres. Even though two-thirds of the national population in the 1880 s were still living outside cities, over half of all criminals prosecuted lived in towns. Weber (1986, p. 40). 
youth, all the more dangerous in the working classes. Their passion for reading and their dreams of travel tapped into anxieties about the social repercussions of an increasingly well-educated and rootless population. The expansion of railways and the spread of literacy went hand in hand, combining to produce a mobile, literate population. ${ }^{47}$ In the space of just over half a century, from the mid-nineteenth century to the outbreak of the First World War, the rate of illiteracy in France plummeted from forty percent to just over two percent. ${ }^{48}$ However while greater literacy and a free, robust print culture appeared to symbolize material progress to some, to others it carried the potential to morally corrupt impressionable readers. The increasing pool of capable readers produced by universal, compulsory primary education and the liberalization of the press as a result of laws passed on 19 July 1881 intensified the authorities' concerns about the contagiousness of anti-social attitudes and behaviours.

Ordinary readers like Jacquiard and Vienny were thus perceived as latently dangerous figures. Moreover, as adolescents, they were seen to belong to a social category inherently characterized by turbulence and insubordinate inclinations which tended to acts of criminality. The link between adolescence and crime was drawn clearly by Albert Giuliani, a doctoral student in law at the University of Dijon in the 1900s, who began his dissertation with the observation: "adolescents are an army..., an active army of crime". ${ }^{49}$ France could take some comfort from the fact that the high rate of youth criminality was not its shame alone but one shared by other Western nations.$^{50}$ For Gabriel Tarde, this was an important point. In an open letter to the republican education reformer Ferdinand Buisson published in 1897, Tarde declared "the more and more frequent decline of young people into vice and offending, even into crime, is ... not exclusively a French malady in our time; it is also the German malady, the English malady, the European malady". ${ }^{51}$ Nevertheless, because of concerns over France's comparatively sluggish birth rate, the manifestation of high rates of youth criminality of an increasingly violent nature was particularly alarming. ${ }^{52}$

For republicans, the surest means of ensuring the successful prevention of crime was believed to be education. They also considered education to be a shield and sword against the republic's social enemies, both internal and external, preventing

47 Vincent (2003, p. 425).

48 Gillis (2004, p. 1304).

49 Giuliani (1908, p. 11)

50 For comparative purposes, see Mary S. Gibson's work on the treatment of juveniles in Italy. Gibson (2003).

51 Tarde (1897, p. 197). Young people were far more frequently convicted of minor offences like vagrancy and begging - among the most visible types of offence brought before the French courts in the nineteenth century. Kaluszynski (2002, p. 118). Together, vagrancy, begging and theft, accounted for the bulk of young offenders placed in colonies pénitentiaires. In 1896, 86 per cent of boys in detention had been placed there as a result of these offences. Grosmolard (1900, p. 551).

52 By 1911, 34.9 per cent of the French population was under the age of twenty-one, whereas in Germany the proportion was 43.7 per cent. McMillan (2000, p. 141). On the population crisis, see Hunter (1962, pp. 490-503). In his open letter to Buisson, Tarde cited statistics indicating that the average annual murder rate among youths in 1894 was more than double the rate it had been in 1856 . The fact that this only amounted to around two cases per year - or just one per cent of the more than two hundred murders committed every year by adults - was apparently considered immaterial. Tarde (1897, p. 194). 
the nation from either relapsing into an autocratic (clerical) monarchy or spiralling into revolution. The primary school, with its secular programme of moral and civic education, played a crucial role in this process. ${ }^{53}$ Teachers were elevated to the position of "high priests of nation-worship" ${ }^{54}$ acting as the "ideological cement" of society. ${ }^{55}$ Historians have argued that, in fact, republicans were driven by similar motives to those of preceding regimes, from whom they sought to distance themselves, and that their programme of moral education "seems only the substitution of secular propaganda supporting a bourgeois republic for the old religious propaganda which supported aristocratic monarchy, and thus a political necessity, as it had been in the First Republic". 56

From the 1890s onwards, increasing numbers of critics began to draw attention to the shortcomings of republican educational institutions. Laws governing education and labour passed in the 1880s and 1890s built on child protection reforms introduced earlier in the century, establishing universal age thresholds of real and symbolic significance and marking out definite boundaries between childhood and adolescence - stages that had been fluid and porous in the eyes of the State. ${ }^{57}$ Historians agree that education in republican primary schools and military service were key mechanisms for the formation of a sense of national identity in the second half of the nineteenth century. ${ }^{58}$ Critics of republican pedagogy pointed to the fact that State-run schools only catered for children up to the age of thirteen, leaving adolescents to navigate their transition into the paid labour force alone.$^{59}$ This was the "dangerous age", observed the prominent jurist Henri Robert, the moment when, having completed primary school and "imbued with a rudimentary knowledge, the adolescent believes himself qualified for anything. He cannot yet earn his own living. He will easily acquire the habit of laziness and [keeping] bad company". ${ }^{60}$ Impatient to exercise their rights as citizens and ambitions as adults, the children produced by the republican education system were frustrated by a society which kept them suspended in a sort of limbo until they came of age. For boys this institutional neglect lasted until entry into the military, while for girls it continued for the rest of their lives. ${ }^{61}$

Journalist and social commentator Henry Bérenger attributed the particular

53 On secular morality in the Third Republic, see Stock-Morton (1988, pp. 83-168).

${ }^{54}$ Singer (1977, p. 414).

55 Azéma, Winock (1970, p. 131).

56 Stock-Morton (1988, p. 95).

57 On the earlier phases of child protection, see Heywood (1988); Weissbach (1989). The pioneering study on the history of adolescence in nineteenth-century France by Agnès Thiercé remains the authoritative work in the field. Thiercé (1999).

58 Perrot (1997, p. 79); Loriga (1997, pp. 35-36); Weber (1976, pp. 78, 84, 292-302); Furet, Ozouf (1977, p. 81, 205-302); Wohl (1979, p. 207).

59 Berlanstein (1984, p. 18). The situation was made worse by the absence of apprenticeships, which had been on the decline for decades since at least the time of the Revolution of 1789. Bonzon (1894, p. 182). In the absence of formal contracts young apprentices in Paris in the 1840s were compelled to find work where they could, were often left idle and thus at risk of falling into criminal activity. Haine (1992, p. 455). See also Perrot (1997).

60 Robert (1913, p. 109).

61 Compulsory military service was introduced in France in 1798, requiring the participation of all males aged twenty to twenty-five. This created a new solidarity within male youth based on age. Roynette (2003, p.281). For a general overview of the history of conscription, see Bozon (1981). 
concentration of interest on children under thirteen to the republicans' attempt to undermine the authority of the Catholic Church. ${ }^{62}$ This allegation was supported by the relegation of religious teaching from the school curriculum and the emergence of the certificat d'études primaires as the principal indicator of a young person's maturity, supplanting Holy Communion. ${ }^{63}$ Jurist Georges Bonjean told a meeting of the Société Générale des Prisons that the certificat, required for a young person's eligibility for employment, was in fact "a certificate of incapacity," signifying that the child knew "absolutely nothing from a general point of view" and served purely to infatuate the child with a false sense of entitlement "in a dangerous way". ${ }^{64}$ Given that young people of higher social standing would have continued on in their education, it is clear that the concern was directed squarely at working-class youth. In response to the neglect, the 1890s saw the establishment of a republican programme of higher primary education (enseignement primaire supérieur) alongside a flurry of organizations and festivals, both religious and secular: the boy scouts, colonies de vacances, Catholic youth groups, sporting clubs and fêtes de l'adolescence. ${ }^{65}$

But it was not just the duration of republican education that was held to blame for disorderly youth, it was also the quality of the moral instruction it offered. The fact that the provision of universal primary education had occurred at the same time as a spike in the rate of juvenile offending led some observers to draw a connecting line of causation between them. For criminal justice reformers Louis Albanel and Henri Joly, the main problem with the ambitions of republicans for their education system was that - despite the programme of morale läque - it concentrated too much on children's intellectual development and too little on their moral upbringing. Albanel declared that Georges Danton's maxim that "after bread, education is people's first need" only had meaning if children were given an éducation (upbringing) as well as instruction (education). ${ }^{66}$ Fellow jurist Paul Drillon similarly condemned republican schools for failing to instil an adequate sense of morality in the nation's young. ${ }^{67}$ In his criticism of the programme of civic morality taught in republican schools (which had replaced catechism classes) Drillon betrayed a strong class prejudice. Unconvinced of the republican curriculum's capacity to elevate children's souls, especially those of the lower social classes, Drillon declared that "it is all well and good to talk of the duties of the citizen, of altruism and solidarity, of respect for one's self and one's fellow man," but such ideas would have more traction among "superior intelligences, already raised beyond the common level by their origins and

62 Bérenger (1895, p. 227). Similar comments were made by Paul Beurdeley, mayor of Paris' $8^{\text {th }}$ arrondissement. Beurdeley (1895, p. 204).

63 In 1910, in an effort to draw more children into the faith, Pope Pius X issued an encyclical which set the moment of first receiving Communion around age seven. Martin-Fugier (1990, pp. 329-330). On the reaction to and application of the papal encyclical in France, see Gresillon (1987).

64 Bonjean, Revue pénitentiaire: Bulletin de la Société Générale des Prisons (June 1904, p. 769).

${ }_{65}$ For general surveys on the treatment of adolescence, see Maurice Crubellier (1979, chapters 14 \& 15); Alaimo $(1988,1994)$. On the colonies de vacances, see Downes (2002). On the fête de l'adolescence, see Pomfret (2004); Thiercé (1999, pp. 180-183). On sport, see Weber (1971, pp. 7098).

${ }_{66}$ Albanel (1900, pp. 138-139). See also Joly (1904, p. 189).

67 Joly (1904, p. 189). 
their studies", leaving the popular masses unaffected. ${ }^{68}$ The republican curriculum's emphasis on developing understandings of individual rights at the expense of collective responsibilities was seen to feed criminality.

The case of Jacquiard and Vienny was thus played out against this background of tense ideological debate. Figaro journalist Georges Claretie pointed out the irony that it should be Auxerre - the birthplace of distinguished republican statesmen Paul Bert - that played host to the trial of the two boys. Decades earlier, alongside Jean Macé and Jules Ferry, Bert had been instrumental in democratizing access to free, secular education, and he was commemorated in his hometown by both a bridge and a statue. ${ }^{69}$ For Bert, education provided the key to fighting superstition, forging equality, and buttressing political democracy. Shortly before the passing of the Ferry laws on education, Gabriel Compayré, republican député and probably the single most important ambassador for republican pedagogy, paid tribute to the educational ambitions of the revolutionaries of 1789 , proclaiming: "it was the men of the Revolution [of 1789] who were the first to want in good faith to generalize education, to shed light on all the ranks of society, to sow the schools in all the villages. They did not want education for the upper classes to be only a fragile literary varnish, the art of writing well and speaking well; they pursued the ideal of a moral, patriotic education, which forms man, the citizen, still more than wit". ${ }^{70}$

Victor Hugo shared this belief in the power of education, believing it to hold the key to preventing criminality. At the end of his 1834 short novel Claude Gueux, a parliamentary orator issues an impassioned declaration on education's role in combatting crime: "This head of the man of the people, improve it, cultivate it, water it, fertilize it, moralize it, use it; you will not need to cut it off"' ${ }^{71}$ Not all of Hugo's contemporaries shared his optimistic formula. ${ }^{72}$ By the century's end, the proclamation commonly attributed to Hugo that "to open a school is to close a prison" was problematized, largely because of the secularization of education. The contention that education in general and literacy in particular could somehow provide a tonic to criminality might still have found some support at the close of the nineteenth century - the poet Eugène Manuel wrote that "whoever knows how to read is a man saved" - but overall the equation had lost much of its persuasive force. ${ }^{73}$ Indeed Italian criminologist Cesare Lombroso declared education programmes not only useless but counterproductive, as they armed criminals with new anti-social weapons - an argument similarly advanced in Britain in the 1820s - and he called for the closure of all schools within prisons. ${ }^{74}$

In 1912, the year that saw juvenile courts established in France, ${ }^{75}$ medical doctor N. Baldet argued that education was a double-edged sword, improving social

\footnotetext{
$\overline{68}$ Drillon (1905, p. 34). Henry Fouquier, journalist and former press censor during the Second Empire, concurred, writing that the republican curriculum of morale laïque was suited to adult philosophers, but it taught children little about their practical civic duties. Figaro, 20 July 1889.

69 Claretie (1911, p. 218).

70 Compayré (1879, pp. 421-422).

71 Hugo (1883, p. 114).

72 Wright (1983, p. 112)

73 Manuel (1870, p. 37).

74 Lombroso (1909, p. 216); Shore (1999, pp. 38-39).

75 Niget (2009).
} 
standards but simultaneously fostering discontent for the socially disenfranchised. There was nothing more wondrous, more essential, but also more dangerous, he proclaimed, than universal primary education. While equal access to basic education was of indisputable utility, Baldet maintained, it was essential to recognize the fallout it produced:

Many young people have been turned off manual labour; we have thrown ... into young minds which were not ready to receive them and to develop them - ideas that they were not able to understand; and they imagined themselves - because they had some certificate or other, because they had been to school, because they knew how to read and write - that they knew everything, and that physical labour was no longer made for them. ${ }^{76}$

For Baldet, compulsory education, which cultivated a distaste for manual labour among children of the working classes, was likely to fuel further social tensions, rather than relieve them.

Amid all the criticisms levelled against republican pedagogy, there were some commentators who rallied to its defence, among them philosopher Alfred Fouillée. In an article published in the Revue des deux mondes in 1897, Fouillée argued that it was simply a coincidence that the introduction of universal education and the increase in juvenile offending rates had occurred simultaneously - one did not explain the other. ${ }^{77}$ Although raw figures indicated that children attending State schools broke the law more often than those who attended private schools, Fouillée maintained that these figures were deceptive since State schools were not selective. ${ }^{78}$ While not uncritical of the republican curriculum, acknowledging that it should do more to develop children's morals not just their intellects, ${ }^{79}$ overall Fouillée found that it was poor levels of attendance and inadequate parental supervision that were largely at fault. ${ }^{80}$ In other words, the problem was social, not ideological.

Aged fourteen and sixteen respectively at the time of their crime, Vienny and Jacquiard were at a conceptually awkward stage - not quite children, but also not yet at their full maturity. Authorities agonized over how to most effectively manage youths who were beyond the age of compulsory school attendance, but not yet old enough either to exercise their civic rights, with which they had been thoroughly familiarized on the benches of the republican primary school, or to earn a full wage. Indeed even if they had not committed a crime, the Jully perpetrators would have still been considered troublesome figures in contemporary society purely on account of their age. Too old for compulsory schooling, but too young for entry into the military, the boys belonged to an age group which had to a large extent fallen outside the republican bureaucracy's net. As ideas about children and childhood set down firmer roots, the next phase of life was thrown into greater relief. The mild-

\footnotetext{
$76 \quad$ Baldet (1912, pp. 13-14).

77 Fouillée (1911, p. 156).

78 Of a sample of one hundred primary school-aged children prosecuted by criminal courts in Paris, for instance, only two attended a religious primary school and out of one hundred children convicted and imprisoned at Petite Roquette only eleven had been attending a religious school. Fouillée (1897, p. 426).

79 Fouillée (1897, p. 428).

80 Fouillée (1911, p. 161).
} 
mannered, obedient, diligent child was pitted against the wild, recalcitrant, indolent adolescent - powerfully incarnated by Vienny and Jacquiard.

\section{CONCLUSION}

On 4 June 1910, the jury handed down their verdict: they found that the boys had committed the five counts of murder with discernement and without any attenuating circumstances. Jacquiard was sentenced to death, a decision that President Fallières commuted the next month to life in a penal colony, which, according to one source, was met with the same "unanimous protestations" as the commutation of the death sentence for child rapist and murderer Albert Soleilland in 1907. ${ }^{81}$ Vienny, meanwhile, was sentenced to twenty years' detention in a colonie correctionelle - this lesser sentence on account of his having been under sixteen at the time of the crime, a status which automatically protected him from the harshest penalties. Although Jacquiard had been aged over sixteen at the time of the crime, following a change to legislation in 1906 which extended the age of criminal responsibility from sixteen to eighteen, the court was required to make a formal assessment according to Article 66 of the Penal Code, just as they were for Vienny, as to whether the boy had acted with or without discernement. Had the court found that Jacquiard had acted without discernment, he would have been acquitted and most likely placed in detention (as was customary) for a period of time determined by the court. In their coverage of the trial, none of the newspapers consulted displayed resistance to the fact that the jury was required to make a statement on the older boy's degree of discernment - perhaps because the evidence against Jacquiard was considered sufficiently compelling to ensure a conviction.

In response to the crime, commentators were quick to point out the boys' various social transgressions, and in so doing tried to justify the importance of retaining sharp distinctions between the classes. The concern about the boys' criminality extended beyond the events of that day in early December to encompass wider anxieties, especially those relating to changing social dynamics. As criminals, adolescents (neither children nor adults), and as educated workers, the liminal status of Jacquiard and Vienny made them highly dangerous figures for French society in the decades before the First World War. The fact that the boys had not been educated in French schools was not immediately germane, as the universal problem of juvenile crime transcended national boundaries and French observers all too easily recognized in the two Swiss youths dangers that also threatened French youths. Changes to children's status in society through education and labour reform universalized a certain model of childhood, as passive and preparatory, while adolescents like Jacquiard and Vienny occupied an ambiguous position between dependency and emancipation. Caught between the dependency of childhood and the independence of adulthood, the adolescent symbolized the dangers of a society in the process of evolving into a modern democracy. For the authorities of law and order, Jacquiard and Vienny's great expectations and their alleged illusions of grandeur were clear

81 Signorel (1912, p. 28). On the Soleilland case, see Berlière (2003). The frequency of commutations and acquittals at the time contributed to the perception of a "crise de répression". For more on this, see Kalifa (2000). 
indicators of the social problems caused by an overly educated, ambitious young population. Far from preventing crime, education was not always simply a guarantee against criminality; what was more critical still was for children to be protected from exposure to corrupting influences.

The "crime de Jully" knitted together various threads of a longstanding debate in France over the causes and contagiousness of criminality, the perils of adolescence as a stage of life, and, most fundamental of all, a cautionary tale about the dangersactual and symbolic - posed by working-class youths, both educated and uneducated, to the Third Republic social order. In effect Jacquiard and Vienny became cultural reference points for the tensions of a society in transition. As educated and literate individuals, Jacquiard and Vienny were modern subjects contained within the bounds of a traditional society. This played into the hands of enemies of republican education, who believed that, far from "civilizing" children, the curriculum fed discontent and impeded social cohesion. The case exposed the fault lines of a regime desperate to hold on to power but whose cracks were beginning to show under the weight of socialist and anti-secularist opposition. Contemporary debates on the Jully crime laid bare the one crucial and insurmountable contradiction that the republican education system confronted at the end of the long nineteenth century: how to educate politically enfranchised individuals who were to remain socially and culturally subjugated.

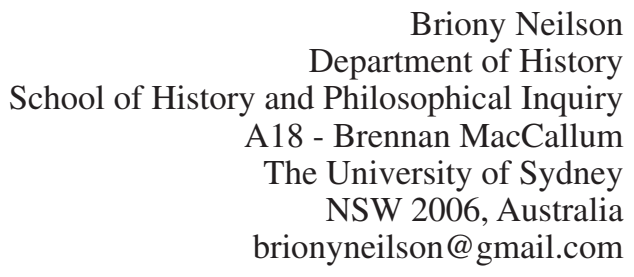

\section{REFERENCES}

Le Courrier de la Montagne

La Croix du Nord

La Dépêche (de Toulouse)

L'Écho de Paris

L'Écho du Tonnerrois

Le Figaro

La Gazette de Lausanne

La Liberté (de Fribourg)

Le Matin

Le Petit journal

Le Petit parisien

Revue pénitentiaire: bulletin de la Société Générale des Prisons

Le Temps

Agulhon, M., La République: de Jules Ferry à François Mitterrand, 1880 à nos jours, Paris, Hachette, 1990. 
Alaimo, K., Adolescence in the popular milieu in France during the early Third Republic: efforts to define and shape a stage of life, $\mathrm{PhD}$ diss., The University of WisconsinMadison, 1988.

Alaimo, K., Adolescence, gender, and class in education reform in France: the development of enseignement primaire supérieur, 1880-1910, French historical studies, 1994, 18, 4, pp. 1025-1055.

Albanel, L., Le crime dans la famille, Paris, Rueff, 1900.

Altick, R., The English common reader: a social history of the mass reading public, 18001900, Chicago, University of Chicago Press, 1957.

Ambroise-Rendu, A.C., Petits récits des désordres ordinaires: les faits divers dans la presse française, de la Troisième République à la Grande Guerre, Paris, S. Arslan, 2004.

Azéma, J.-P., Winock, M., Naissance et mort: la Troisième République 1870-1914, Paris, Calmann-Lévy, 1970.

Baldet, N., La criminalité juvénile: la conscience et la volonté, Paris, Chagniat, 1912.

Barrès, M., Les déracinés, Paris, Bibliothèque-Charpentier, 1897.

Becker, H. S., Outsiders: studies in the sociology of deviance, New York, The Free Press, 1973.

Bérenger, H., De l'école au régiment: enquête sur l'éducation des adultes, Revue bleue, juillet-décembre 1895, 4, pp. 227-233, 269-273, 297-301, 339-343.

Berenson, E., The trial of Madame Caillaux, Berkeley, University of California Press, 1993.

Berlanstein, L.R., The working people of Paris, 1871-1914, Baltimore, Johns Hopkins University Press, 1984.

Berlière, J.-M., Le crime de Soleilland (1907): les journalistes et l'assassin, Paris, Tallandier, 2003.

Beurdeley, P., Après l'école: Le placement des enfants, Revue pédagogique, mars 1895, 26, 3, pp. 204-210.

Bonzon, J., La législation de l'enfance, 1789-1894: cent ans de lutte sociale, Paris, Guillaumin, 1894.

Bozon, M., Les conscrits, Paris, Berger-Levrault, 1981.

Camus, J., Diey, M., La tuerie de Jully: 10 décembre 1909, Châtillon-sur-Seine, Association des amis du Châtillonais, 2009.

Chauvaud, F., Les figures du monstre dans la seconde moitié du XIX ${ }^{\mathrm{e}}$ siècle, Ethnologie française, juillet-septembre 1991, 21, 3, pp. 243-253.

Chevalier, L., Classes laborieuses et classes dangereuses, Paris, Plon, 1958.

Claretie, G., Drames et comédies judiciaires, deuxième année, 1910, Paris, Berger-Levrault, 1911.

Coffignon, A., L'enfant à Paris, Paris, Ernest Kolb, 1889.

Compayré, G., Histoire critique des doctrines de l'éducation en France depuis le XVIe siècle, 1, Paris, Hachette, 1879.

Crubellier, M., L'enfance et la jeunesse dans la société française, 1800-1950, Paris, A. Colin, 1979.

Donzelot, J., La police des familles, Paris, Éditions de Minuit, 1977.

Downes, L. L., Childhood in the promised land: working-class movements and the colonies de vacances in France, 1880-1960, Durham, Duke University Press, 2002.

Drillon, P., La jeunesse criminelle, Paris, Bloud, 1905.

Elwitt, S., The making of the Third Republic: class and politics in France, 1868-1884, Baton Rouge, Louisiana State University, 1975.

Faron, O., Father-child relations in France: changes in paternal authority in the nineteenth and twentieth centuries, History of the family, 2001, 6, 3, pp. 365-375. 
Fass, P., Making and remaking an event: the Leopold and Loeb case in American culture, Journal of American History, 1993, 80, 3, pp. 919-951.

Fontaine, J.P., Les mystères de l'Yonne, avec la collaboration de Nathalie Marx, Romagnat, de Borée, 2005.

Fouillée, A., Les jeunes criminels, l'école et la presse, Revue des deux mondes, janvier 1897, 67,1, pp. 417-449.

Fouillée, A., La France au point de vue moral, 5e édition, Paris, F. Alcan, 1911.

Furet, F., Ozouf, J., Lire et écrire: l'alphabétisation des Français de Calvin à Jules Ferry, 1, Paris, Éditions de Minuit, 1977.

Gibson, M. S., The criminalization of youth in late nineteenth- and early twentieth-century Italy, in Knafla, L.A. (ed.), Crime, punishment and reform in Europe, Westport, Praeger, 2003, pp. 121-144.

Gillis, A. R., Institutional dynamics and dangerous classes: reading, writing and arrest in nineteenth-century France, Social forces, 2004, 82, 4, pp. 1303-1332.

Giuliani, A., L'adolescence criminelle: contribution à l'étude des causes de la criminalité toujours croissante de l'adolescence et des remèdes à y apporter, Villefranche, Imprimerie du Réveil du Beaujolais et du Sud-Est, 1908.

Gresillon, S., De la communion solennelle aux fêtes de la foi, in Cabantous, A., Delumeau, J., (dir.), La première communion: quatre siècles d'histoire, Paris, Desclée de Brouwer, 1987, pp. 220-232.

Grosmolard, J., Jeunes détenus passibles de la relégation, Archives de l'anthropologie criminelle, 1900,15 , pp. 569-597.

Guillot, A., L'enfant vagabond et l'école de préservation, La nouvelle revue, 1893, 82, pp. 449-468.

Haine, W. S., The development of leisure and the transformation of working-class adolescence, Paris 1830-1940, Journal of family history, 1992, 17, 4, pp. 451-476.

Harris, R., Murders and madness: medicine, law and society in the fin de siècle, Oxford, Clarendon Press, 1989.

Hendrick, H., Images of youth: age, class and the male youth problem, 1880-1920, Oxford, Clarendon Press, 1990.

Hendrick, H., Histories of youth crime and justice, in Goldson, B., Muncie, J. (Eds), Youth, crime and justice: critical issues, London, Sage, 2006, pp. 3-17.

Heywood, C., Childhood in nineteenth-century France: work, health, and education among the 'classes populaires', Cambridge, Cambridge University Press, 1988.

Hugo, V., Le dernier jour d'un condamné; Claude Gueux, Paris, E. Hugues, 1883.

Hunter, J. C., The problem of the French birth rate on the eve of World War I, French historical studies, 1962, 2, 4, pp. 490-503.

Jackson, L. A., Child sexual abuse in Victorian England, London, Routledge, 2000.

Joly, H., Les lectures dans les prisons de la Seine, Archives de l'anthropologie criminelle, 1888, 3, pp. 305-317.

Joly, H., L'enfance coupable, Paris, V. Lecoffre, 1904.

Kalifa, D., L'encre et le sang : récits de crimes et société à la Belle Époque, Paris, Fayard, 1995.

Kalifa, D., Magistrature et "crise de la répression" à la veille de la grande guerre, 1911-1912, Vingtième siècle: revue d'histoire, 2000, 67, pp. 43-59.

Kaluszynski, M., La république à l'épreuve du crime : la construction du crime comme objet politique, 1880-1920, Paris, LGDJ, 2002.

Lombroso, C., Traitement moral du jeune criminel, in Spiller, G. (ed.), Papers on moral education, communicated to the first International Moral Education Congress, London $1908,2^{\text {nd }}$ edition, London, David Nutt, 1909, pp. 216-222. 
Lyons, M., Reading culture and writing practices in nineteenth-century France, Toronto, University of Toronto Press, 2008.

Manuel, E., Les ouvriers: drame en un acte, en vers, Paris, Michel Lévy, 1870.

Martin-Fugier, A., Bourgeois rituals, in Perrot, M. (ed.), A history of private life, 4, Arthur Goldhammer, trans., Cambridge, Belknap Press, 1990, pp. 261-338.

McMillan, J. F., France and women, 1789-1914: gender, society and politics, London, Routledge, 2000.

Meyer, P., L'enfant et la raison d'État, Paris, Seuil, 1977.

Neilson, B., The age of morality: youth, criminal responsibility, and juvenile justice reform in Third Republic France, 1877-1912, PhD diss., University of Sydney, 2012.

Niget, D., La naissance du tribunal pour enfants: une comparaison France-Québec, 19121945, Rennes, Presses Universitaires de Rennes, 2009.

Nilan, K., Incarcerating children: prison reformers, children's prisons, and child prisoners in July Monarchy France, PhD. diss., Yale University, 1992.

Nilan, C., Hapless innocence and precocious perversity in the courtroom melodrama: representations of the child criminal in a Paris legal journal, 1830-1848, Journal of family history, 1997, 22, 3, pp. 251-285.

Norris, K. H., Reinventing childhood in fin-de-siècle France: child psychology, universal education, and the cultural anxieties of modernity, $\mathrm{PhD}$ diss., University of California, Berkeley, 2000.

Nye, R. A., The origins of crowd psychology: Gustave Le Bon and the crisis of mass democracy in the Third Republic, London, Sage Publications, 1975.

Nye, R.A., Crime, madness and politics in modern France: the medical concept of national decline, Princeton, Princeton University Press, 1984.

Olivier, V., Un sang-froid et un courage au-dessous de leur âge: la construction de la figure du jeune sauveteur, 1870-1938, Annales de Bretagne et des Pays de l'Ouest, 2009, 116, 1, pp. 73-86.

Pearson, G., Hooligan : a history of respectable fears, London, Macmillan, 1983.

Perrot, M., Worker youth: from the workshop to the factory, in Levi, G., Schmitt, J.-C. (Eds), A history of young people in the west, 2, Carol Volk, trans., Cambridge, Belknap, 1997, pp. 66-117.

Perrot, M., Dans le Paris de la Belle Époque: les “apaches," premières bandes des jeunes, in Perrot, M., Les ombres de l'histoire : crime et châtiment au XIX ${ }^{e}$ siècle, Paris, Flammarion, 2001, pp. 351-364.

Pomfret, D. M., "A muse for the masses:" gender, age, and nation in France, fin de siècle, American historical review, 2004, 109, 5, pp. 1439-1474.

Robert, H., La criminalité juvénile, La revue de Paris, novembre 1913, pp. 100-111.

Robert, H., Morale et philosophie: crimes d'enfants, Université des annales, 15 janvier 1912, pp. 381-395.

Rose, N., Inventing ourselves: psychology, power and personhood, Cambridge, Cambridge University Press, 1997.

Roynette, O., Les représentations de la masculinité chez les médecins militaires au XIX siècle, in Bardet, J.-P., Luc, J.-N., Robin-Romero, I., Rollet, C. (dir.), Lorsque l'enfant grandit: entre dépendance et autonomie, Paris, Presses de l'Université Paris-Sorbonne, 2003, pp. 281-290.

Schafer, S., Children in moral danger and the problem of government in Third Republic France, Princeton, Princeton University Press, 1997.

Schnapper, B., La correction paternelle et le mouvement des idées au dix-neuvième siècle, 1789-1935, Revue historique, 1980, 263, 2, pp. 319-349. 
Shapiro, A.-L., Breaking the codes: female criminality in fin-de-siècle Paris, Stanford, Stanford University Press, 1996.

Shore, H., Artful dodgers: youth and crime in early nineteenth-century, London, Rochester, NY, Royal Historical Society/Boydell Press, 1999.

Signorel, J., Le crime et la défense sociale (suite), Revue générale d'administration (ministère de l'Intérieur), janvier 1912, pp. 13-33.

Singer, B., From patriots to pacifists : the French primary school teachers, 1880-1940, Journal of contemporary history, 1977, 12, 3, pp. 413-434.

Stock-Morton, P., Moral education for a secular society: the development of morale laïque in nineteenth-century France, Albany, State University of New York Press, 1988.

Stone, J., The search for social peace: reform legislation in France, 1890-1914, Albany, State University of New York Press, 1985.

Surkis, J., Secularization and sexuality in Third Republic France, 1870-1920, PhD diss., Cornell University, 2001.

Surkis, J., Sexing the citizen: morality and masculinity in France, 1870-1920, Ithaca, Cornell University Press, 2006.

Tarde, G., La jeunesse criminelle : lettre à Ferdinand Buisson, Revue pédagogique, 1897, 30, 3, pp. 193-215.

Thiercé, A., Histoire de l'adolescence, 1850-1914, Paris, Belin, 1999.

Tomel, G., Rollet, H., Les enfants en prison, Paris, Plon, 1891.

Toth, S., The Contard affair: private power, state control, and paternal authority in fin-desiècle France, Journal of Historical Sociology, 2010, 23, 2, pp. 185-215.

Vincent, D., The progress of literacy, Victorian studies, 2003, 45, 3, pp. 405-431.

Weber, E., Gymnastics and sport in fin-de-siècle France: opium of the classes ?, American historical review, 1971, 76, 1, pp. 70-98.

Weber, E., Peasants into Frenchmen: the modernization of rural France, 1870-1914, Stanford, Stanford University Press, 1976.

Weber, E., France, fin de siècle, Cambridge, Belknap Press, 1986.

Weissbach, L. S., Child labor reform in nineteenth-century France: assuring the future harvest, Baton Rouge, Louisiana State University Press, 1989.

Wohl, R., The generation of 1914, Cambridge, Harvard University Press, 1979.

Wright, G., Between the guillotine and liberty: two centuries of the crime problem in France, New York, Oxford University Press, 1983. 